\title{
Smart Home Security System Design Sensor Based on Pir and Microcontroller
}

\author{
Pristisal Wibowo \\ Faculty Engineering Universitas Pembangunan Pancabudi Medan, India
}

Solly Aryza Lubis

Faculty Engineering Universitas Pembangunan Pancabudi Medan, India

Hermansyah

Faculty Engineering Universitas Pembangunan Pancabudi Medan, India

Hamdani

Faculty Computer Science Universitas Pembangunan Pancabudi Medan, India

\section{Zuraidah Tharo}

Faculty Engineering Universitas Pembangunan Pancabudi Medan, India

Received: August 1, 2017 Accepted: October 22, 2017 Published: October 25, 2017

doi:10.5296/ijgs.v1i1.12053 URL: http://doi.org/10.5296/ijgs.v1i1.12053

\begin{abstract}
Technological developments are so rapid at this time to make people want always to be creative and trigger to create something new which can be applied and can use quickly and practically and control from close range and distance. In this research how to design home security system using PIR sensor (Passive Infra Red) based on microcontroller. Where this safety will work if the PIR (Passive Infra Red) sensor detects any human being that does not want to enter into the house, and then the micro controller process and instructs cell phone 1 to send an alarm signal in the form of SMS (Short Message Service).
\end{abstract}




\section{Macrothink \\ International Journal of Global Sustainability \\ ISSN 1937-7924 \\ 2017, Vol. 1, No. 1}

Keywords: Sensor PIR (Passive Infra Red), Microcontroler, Cellphone

\section{Introduction}

Technological developments so rapidly today that people always want to be creative and trigger to create something new which can be applied and can use quickly and practically. In the science of technology has many inventions that are very useful for humans one of them is the sensor, where a sensor is a tool used to detect and often serves to measure the magnitude. A sensor is a type of transducer used to convert mechanical, magnetic, heat, ray and chemical variations into the voltage and electric current. Technological advancement is needed to create a security system because the difficulty of the current economy to make people act criminally by theft where the target of the theft of the houses left by the owner. From there that makes the worries if we leave the house, to overcome the problem then this research will discuss home security system using sensors PIR (Passive Infra Red) based on microcontroller. Where the system designed with electronic devices consisting of PIR sensors, microcontroller arduino uno where this tool is used as a storage and execute data, which has been in the program first from here it will form a device that can identify the human presence and can connect with homeowners remotely.

\section{Systems Plan Design Smart Security}

The system has designed several blocks, namely: input/output block, the micro controller block,

networking block and controlling/monitoring devices block. The plan design has seen in Figure 1. Detailed explanations of each block are as follows. I/o block consists of two pieces of PIR (Passive Infra-Red) motion sensor and an LM35 temperature sensor as inputs and some lamps, sockets, relay, and buzzer as out signals. The passive infrared sensor is used to detect the presence of motion. The sensor readings are used to turn off the lights if there is no activity and turn on the lights otherwise. Also, this sensor is also used for security systems to detect suspicious movements. If it detects any suspicious movement, an alarm (buzzer) will sound. An LM35 is functioning as temperature monitoring. This sensor also serves as an input to execute some coil. The coil will in on condition when the temperature exceeds a certain limit. This condition will activate a fan or Air Condition (AC) while connected to the coil. 


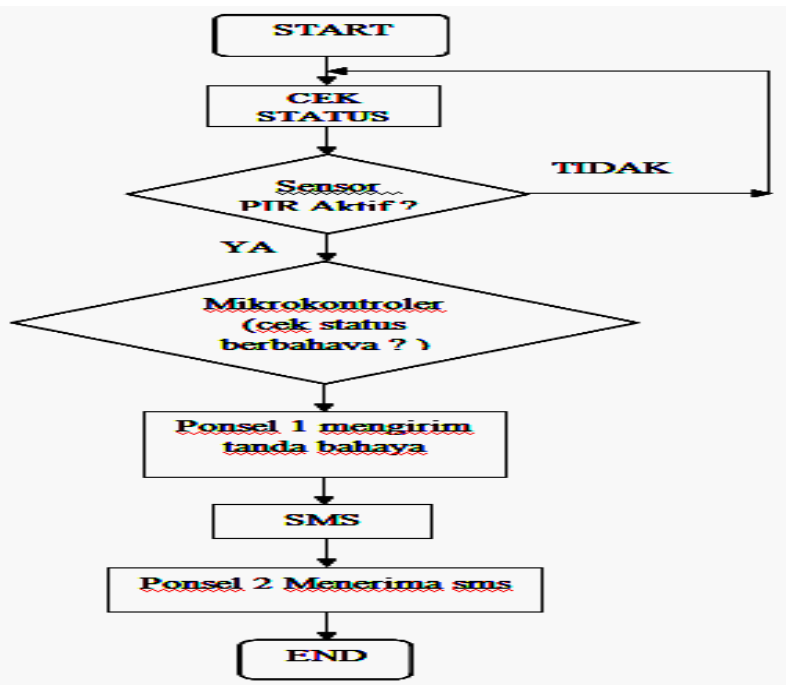

Figure 1. Block diagam proposed system

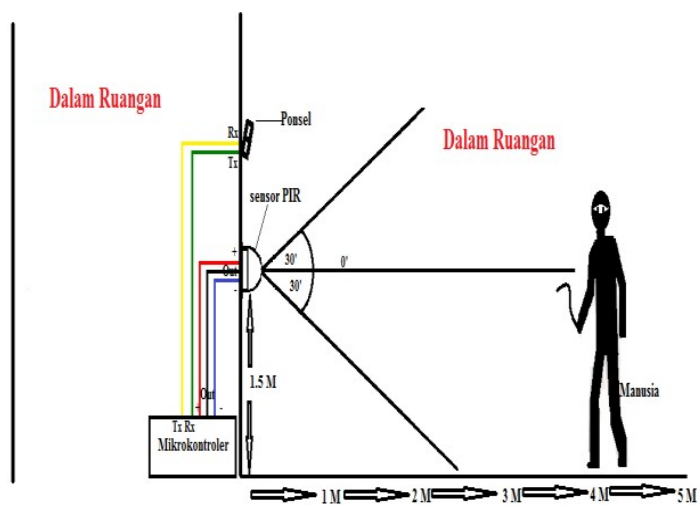

Figure 2. Connection sensor Pir to object

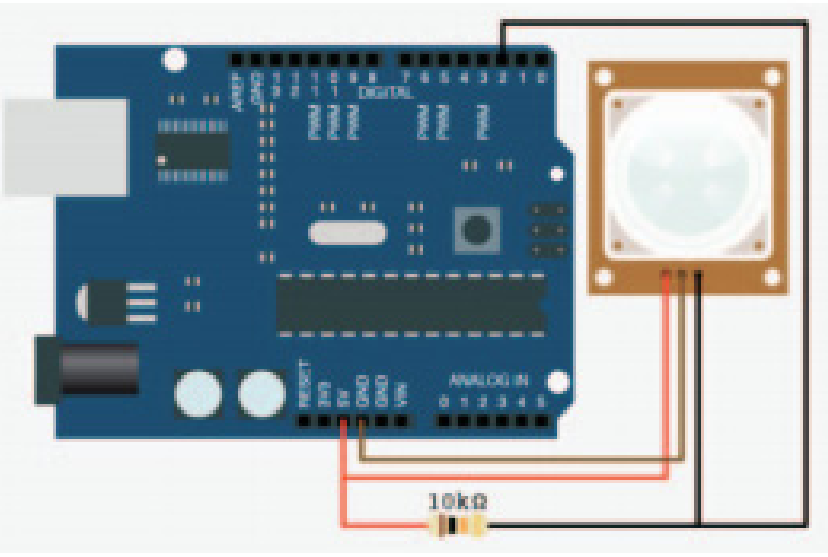

Fiureg 3. Connection of Pir sensor 


\section{Methodologi Research}

This research has conducted in Dam Nongsa housing with house type 60, length 6 meters and 10 meters wide. Following the type 60 house plan and simulation of theft. If we look at the picture, the sensor was installed in the area where it was assumed that the unwanted person or the thief enters from the front side marked by a red or rear arrow of the house characterized by a blue arrow and passes through the sensor coverage area at Mark with a yellow line, so to secure room two which there are valuables, the sensor can easily receive infrared waves and then in the process by the micro controller to instruct the phone to send sms alarm to the homeowner.

\subsection{Hardware Design}

Sensor PIR is a sensor used for security sensors that will place in a place or point that is passed by the object to detect the object quickly. Therefore, in the design of this sensor PIR sensor paired in the room of the house that is at the outlet of human entrance or the area around the door, this is done because the predicted people were going through the path to enter the house. In addition to maximizing the security function of one area of the house. Because this sensor works when receiving infrared rays from the human body, the sensor is placed at the height of 1.5 meters from the floor surface. So looking at the altitude of the average human $>1.5$ meters then allows the sensor to detect only humans.

\subsection{Software Design (software)}

The design of software (software) in this study is necessary for the planned system to work properly. The design of the program on this project using the software compiler CodeVisionAVR V2.03.4. Use of this software is a form of network optimization of all security systems on the run. The system of this project has the primary purpose of sending alarm alerts in the form of SMS (Short Message Service) to homeowners.

\section{Experimental Results}

A small smart home system has been designed. All of equipment needed, Arduino microcontroller system and network devices connected as planned. Web monitor display to know any status of home condition. Based on this figure, it can be seen there are 4 pieces button: the first and second buttons are used to control lights, the third button is used to activate the socket, while the fourth button is used to update the temperature automatically. Below the button status, monitor shows room temperature, fan socket status, PIR status and Lamp status as well. Generally, HP web monitor display is the same as in laptop.

A small smart home system has been designed. All of the equipment needed, Arduino micro controller system and network devices connected as planned. Figure 4 shows prototype Small smart home system. Web monitor display to know any status of a home condition shown in Figure 5. Based on this figure, it can see there is four pieces button: the first and second buttons used to control lights, the third button is used to activate the socket, while the fourth button is used to update the temperature automatically. Below the button status, a monitor shows room temperature, fan device status, PIR status and Lamp status as well. Hp web screen display is the same as in the laptop. 


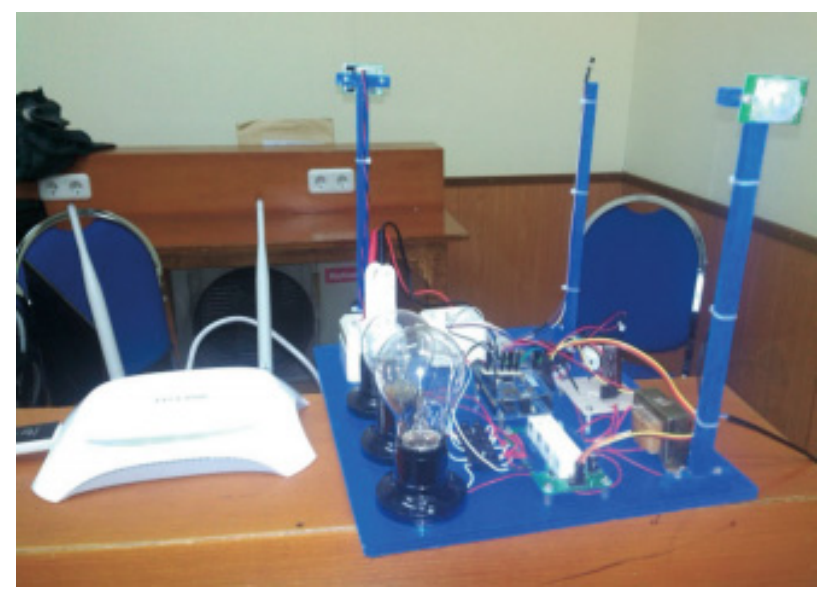

Figure 4. Kit small smart home system

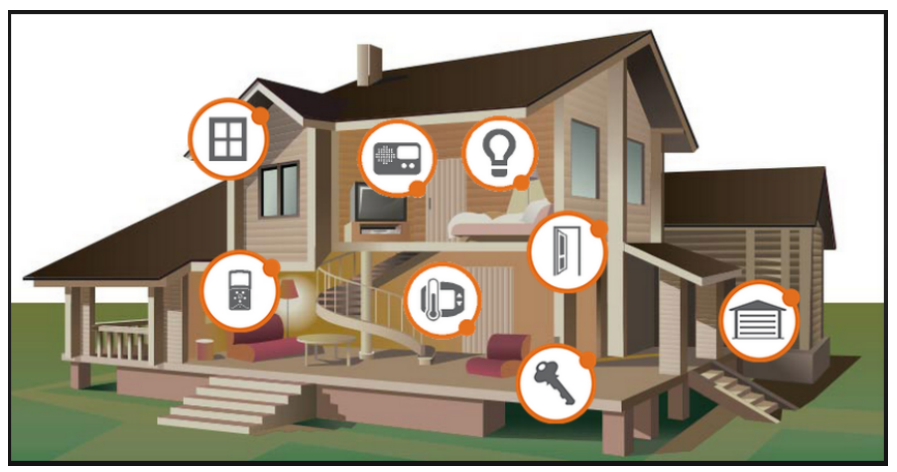

Figure 5. Connection smart security for house

Some experiment has been conducted to know system reliability. Tests are performed in lab by testing all sensors, relays, sockets and buzzer. Table 1 shows the test results.

Table 1. Test Result

\begin{tabular}{|c|c|c|c|c|c|c|c|}
\hline \multirow{2}{*}{$\begin{array}{l}\text { Tegangan } \\
\text { INPUT' } \\
\text { VDC }\end{array}$} & \multirow{2}{*}{$\begin{array}{l}\text { Jarak } \\
(\mathrm{Cm})\end{array}$} & \multirow{2}{*}{$\mid \begin{array}{l}\text { Tegangan } \\
\text { OUTPU } \\
\text { TVDC }\end{array}$} & \multirow[b]{2}{*}{ Objek } & \multirow{2}{*}{$\begin{array}{c}\text { Waktu } \\
\text { sensor } \\
\text { mendetek } \\
\text { si }\end{array}$} & \multirow{2}{*}{$\begin{array}{c}\text { Lama } \\
\text { pengirima } \\
\text { nSMS }\end{array}$} & \multicolumn{2}{|c|}{ Respon } \\
\hline & & & & & & Terkirim & \\
\hline 6Volt & 100 & 3.26 Volit & M & 0.65 detilk & 5Detik & $\sqrt{ }$ & \\
\hline 6Volt & 200 & $3.26 \mathrm{Volt}$ & M & 0.65 detilk & 5Detik & $\sqrt{ }$ & \\
\hline 6Volt & 300 & 3.26 Volt & M & 0.66 detilk & 5Detik & $\sqrt{ }$ & \\
\hline 6Volt & 400 & 3.26 Volt & M & 0.68 detily & 5Detik & $\sqrt{ }$ & \\
\hline 6Volt & 500 & 3.26 Volt & M & 0.70 detily & 5Detik & $\sqrt{ }$ & \\
\hline
\end{tabular}




\section{Macrothink}

From the table above can be made the characterization of the security system, by providing input voltage of $6 \mathrm{VDC}$, then this security system capable of detecting human to the maximum effective distance of $500 \mathrm{Cm}$ or \pm 5 Meters. Then takes $0.65-0.70$ seconds to recognize people, then process and send alarms in the form of SMS within 5 seconds.

\section{Conclusion}

Based on the results of the research it can be concluded as follows:

The security system can deliver or send alarms via SMS within a distance of approximately $40 \mathrm{KM}$ so that homeowners need not worry if away from home. The sensitivity of the PIR (Passive Infra Red) sensor device is high; it is not recommended to use the module under the following conditions:

A. In a fast changing environment

B. Vibration conditions are strong

C. In places where there is blocking of material (e.g., glass) through IRS that can not pass through a detected area

D. Exposed to direct sunlight

E. Install and direct the wind from the heater or air conditioner to the sensor

With this security system homeowners can get much better information because, with an increasingly advanced communication network, owners can immediately find out if the condition of the house is not safe and can immediately report directly to the local security officer. Scheme state of the mobile network is very influential on the work of this system because this system uses a communication network, in this case, is the GSM (Global System for Mobile) network.

\section{References}

Arifianto, Deni. Kamus komponen. Surabaya: PT kawan pustaka: 2011, hlm 171-172.

Astuti, N. W. (2007). Sistem keamanan ruangan menggunakan sensor passive infra red (PIR) KC7783R dengan mikrokontroler AT89551. Laporan tugas akhir, hlm. 2.

Chandra, Frangky dan Deni Arifianto. Jago elektronika. Surabaya: PT kawan pustaka: 2010, hlm 3 .

Gifson, Albert dan Slamet. (2009). Sistem pemantau ruang jarak jauh dengan sensor passive infra red berbasis mikrokontroler AT89S52. Jurnal telkomnika, 7(3), 202-203.

Lestari, Jati dan Grace Gata. (2011). Webcam monitoring ruangan menggunakan sensor gerak PIR (Passive Infra Red), 8(2).

Pramana, R, (2010). Jaringan computer dan pengamanan.

Rahmalia, D. R. (2012). Sistem pendeteksi keamanan ruangan dengan mikrokontroler ATMega 16 berbasis layanan SMS gateway, 6-7. 


\section{Macrothink}

International Journal of Global Sustainability

ISSN 1937-7924 2017, Vol. 1, No. 1

Syaryadhi, M. (2007). Sistem keran wudhuk menggunakan sensor PIR berbasis mikrokontroler AT89C2051. Jurnal rekayasa elektrika, 6(1).

Tanjung, M. (2009). Analisis sistem sensor infra merah pada oil mist detector (OMD) di PLTD lueng bata banda aceh. Hlm 37-38.

Utami, Siska Noviana dan Wenti anggreini, (2007). Sistem pengendalian keamanan rumah jarak jauh via sms. laporan tugas akhir, hlm 9-12 dan hlm 24.

\section{Copyright Disclaimer}

Copyright for this article is retained by the author(s), with first publication rights granted to the journal.

This is an open-access article distributed under the terms and conditions of the Creative Commons Attribution license (http://creativecommons.org/licenses/by/3.0/). 